\title{
MICAH 4:1-5 AND A JUDEAN EXPERIENCE OF TRAUMA ${ }^{1}$
}

\section{Alphonso Groenewald \\ University of Pretoria}

\begin{abstract}
One should not underestimate the impact suffering has on a community. Therefore in biblical studies we are aware, more than ever before, of the impact traumatic events had on individuals and groups. Trauma studies have become an important part of the textual analysis as the exegete turns to potential markers of trauma in the literary prophecy of the HB. The aim of this article is, first of all, to give an overview of the development of trauma studies, as well the influence trauma studies had on Biblical Studies. Secondly, this article will reflect on trauma and experiences of trauma - especially collective trauma of a community - as portrayed in the book of Micah. This is illustrated by an analysis of Micah 4:1-5, a pericope that is part of a biblical book that seems to accentuate that restoration and transformation can only take place after judgement.
\end{abstract}

Key Words: Micah 4:1-5; Trauma; Trauma Studies; Restoration; Transformation; Judgement

\section{Introduction}

In the prologue to a book on the healing of trauma written in 2014, Bessel van der Kolk writes: ${ }^{2}$

One does not have be a combat soldier, or visit a refugee camp in Syria or the Congo to encounter trauma. Trauma happens to us, our friends, our families, and our neighbours ... traumatic experiences do leave traces, whether on a large scale (on our histories and cultures) or close to home, on our families, with dark secrets being imperceptibly passed down through generations. They also leave traces on our minds and emotions, on our capacity for joy and intimacy, and even on our biology and immune systems ... Trauma, by definition, is unbearable and intolerable... While we all want to move beyond trauma, the part of our brain that is devoted to ensuring our survival (deep below our rational brain) is not very good at denial. Long after a traumatic experience is over, it may be reactivated at the slightest hint of danger and mobilize disturbed brain circuits and secrete massive amounts of stress hormones... These posttraumatic reactions feel incomprehensible and overwhelming. Feeling out of control, survivors of trauma begin to fear that they are damaged to the core and beyond redemption.

Disaster and trauma can strike at any time and often come without any warning; whether it be a terminal disease, crime, terror or a natural disaster. They interrupt the existence of a seemingly strong and healthy individual and transfer the life of this person into the landscape of chaos and death. ${ }^{3}$ Some events may have such an impact on people's lives that one may label them 'traumatic events'. No one remains the same after experiencing the event. The experience of external disastrous events may impact on the psyche of either an individual or a community and cause severe trauma. Trauma is caused when an individual or a community experience loss of orientation and direction. ${ }^{4}$ According to Janoff-Bulman ${ }^{5}$ we can only understand trauma if we can recognise the duality of the human condition, namely 
that human beings are both biological and symbolic creatures. Overwhelming life events are intensely threatening to both biological and symbolic survival. Although death puts an end to psychological suffering, we should not trivialise symbolic survival. Rather, any threat to the latter should be understood in terms of a massive disintegration of the person's symbolic world. For Janoff-Bulman "it is the recognition of our fragility as physical creatures that threatens our psychological integrity".

Trauma and traumatic experiences are part of being human. Although the concept of trauma has become a norm nowadays, the study of trauma and the effect of trauma within the social and psychological contexts only spans a little more than a century. Whereas the use of trauma theory in the field of psychology is a relatively new field of study, this is even to a greater degree the situation in the field of biblical studies. The use of trauma theory in biblical studies is thus in its infancy, which is indeed an exciting prospect as new groundwork can be done in this regard. ${ }^{7}$ Garber ${ }^{8}$ justly infers that

the field of trauma studies is a rather new and constantly evolving field itself. Biblical scholars have an opportunity, then, to contribute greatly to understanding both how ancient victims testified to their traumatic experiences and how the texts that they produced have continued to be a resource for people throughout the ages who turn to these ancient texts in an effort to process their own experiences.

In the last decade or more we have experienced a rise in the interest in the hermeneutical value of trauma as a defining category of suffering experienced by people. According to Frechette $\&$ Boase ${ }^{9}$ this is the result of a development which started in the 1970s as biblical scholars developed an interest in the richness of the psychological, sociological, political as well as economic dimensions of human suffering. In this regard it is important to take notice of a landmark study done by Claus Westermann in 1974, in which he acknowledges the theological significance of the function of lament in the HB and observes that "the lament is the language of suffering; in it suffering is given the dignity of language: It will not stay silent!" 10

The emergence of liberation theology, however, had the most influential impact in this hermeneutical turn towards the human dimensions of the text, especially its focus on different aspects of oppression. Although a hermeneutics of trauma is convergent with such approaches it also promises fresh insights, especially where individual, collective, systemic dimensions of experience interconnect. This development of trauma as a hermeneutical lens is not a methodological approach, but rather a heuristic framework which sensitises the exegete for the interconnectedness between historical events and literary representations. Furthermore, this framework can establish a relationship between traumatic experiences on the one hand and the production and appropriation of texts on the other hand. A hermeneutics of trauma emphasises the fact that language can respond to traumatic experiences in such a way that it not only corresponds to the effects of trauma, but also creates mechanisms of survival, recovery and resilience. ${ }^{11}$

\section{A Short Introduction to the History of Trauma Studies}

This short introduction to the history of trauma research is necessary in order to understand trauma within a theological framework, and even more specifically, within prophetic literature. It is necessary for biblical scholars to first understand what trauma means in its psychological reference in order to engage in interdisciplinary study about it. ${ }^{12}$ Although the phenomenon of trauma has always been part of the history of humankind, the study of trauma is relatively new and spans a little more than a century. ${ }^{13}$ In spite of this relatively short time span the psychological literature which focuses on trauma is nevertheless 
infinite, and therefore it cannot be the goal of this section to provide the reader with a comprehensive account of the historical development of trauma and trauma studies. ${ }^{14} \mathrm{~A}$ number of studies have already provided a detailed overview of this historical development. An example is Judith Herman's classical book, Trauma and Recovery, which was first published in 1992 and outlines this history. ${ }^{15}$ In this section the aim is only to indicate some main developments and positions in the development of trauma studies.

In her book Trauma and Recovery Herman begins her history with the end of the $19^{\text {th }}$ century. ${ }^{16}$ Although the formal study of trauma has a history of approximately 150 years, it was particularly during the last couple of years of the $19^{\text {th }}$ century that theoretical models were developed. The focus of the research which was done during these years was foremost on the connection existing between life-threatening or violent events and the impact these events have on the lives of the individual person or on the community. ${ }^{17} \mathrm{~A}$ major focus during these last years of the $19^{\text {th }}$ century was also the study of hysteria which was commonly diagnosed as a disorder occurring in women. The relationship between trauma and mental illness, associated with this hysteria, was the focus of the works of Charcot, Freud and Beuer. ${ }^{18}$

During the $20^{\text {th }}$ century political movements influenced the development of trauma studies. ${ }^{19}$ Changes in social and societal structures, medical advances as well as a new philosophical outlook promoted the interest in trauma and the subsequent study thereof. In this regard Esterhuizen infers that "[p]hilosophical ideas have greatly influenced the different approaches and studies of understanding of human beings, the world they live in and events that continuously shaped and redefined traumatic concepts". ${ }^{20}$ In the view of Rambo the study of trauma "has also moved away form an exclusively individual look at the psyche to a study of cycles of history and the global and political effects of ongoing violence. The study of trauma has expanded to account for multiple levels of trauma: historical trauma, institutional trauma, and global trauma". ${ }^{21}$

Esterhuizen $^{22}$ states that the way in which trauma is understood goes back to Sigmund Freud - the father of the psychoanalytical theory - who had developed and theorised the concept of psychic trauma already in the early 1880s. Freud - like his teacher Jean-Martin Charcot - interpreted hysteria as the result of traumatic experiences which both men and women experienced in the course of their life-time. We can therefore understand hysterical symptoms better when related to earlier life experiences that caused trauma in the life of the individual. This phenomenon is referred to with the concept 'deferred action', implying that the effects of a traumatic experience(s) only become visible later in a person's life when these experiences are recalled.

For O'Connor ${ }^{23}$ trauma studies arose from "the bloody smear that was the twentieth century". Trauma studies in the $20^{\text {th }}$ century were dominated by the war cycles of this century. Subsequently the focus shifted to the soldiers and the after-effects these military conflicts had on both the individuals as well as the societies. Posttraumatic stress disorder (PTSD) was no longer only an issue belonging to the private sphere, but carried into the public sphere. Indeed, it became a national issue with major political consequences. ${ }^{24}$ After World War I Freud, who did psychoanalytical therapy with some of the soldiers returning from the front, made a simple but profound observation, namely that the past does not stay in the past, but always returns. ${ }^{25}$ In the experience of trauma, the wound is relived in time. Trauma is thus not a once-in-a-lifetime experience, but the "problem of temporality is at the root of the phenomenon". ${ }^{26}$

Any study of trauma therefore needs to focus on the possibility of the return of such an event in the present, as well as its impact on both the present and the future. This can 
happen in diverse and in unaccounted-for ways. The return of the past is the challenge trauma studies have to deal with. Scholars of trauma need to identify the wounds - the marks of an event - which continue in the present long after the event(s) which lie in the past. Trauma is time and again defined and comprehended in categories which surpass the human ability to understand, process and integrate the events of the external world. One can just think of the way in which events like genocide, extreme natural disasters, wars and foreign occupation of territories have a lasting impact on the character - in a negative sense - on communities and nations in the aftermath of these events. ${ }^{27}$

The above events which cause trauma can be described with the relationship between death and life. Trauma is in a psychological, thus not in a literal sense, an encounter with death and the human being(s) are drawn into the sphere of death as these radical experience(s) destroy the familiar world and all knowledge of operating within it. The term 'survival' is used to describe the aftermath of a traumatic event as life takes on a fundamentally different characteristic as it is always mixed with an experience of death. ${ }^{28}$

\section{The Impact of Trauma Studies on Theology and Biblical Studies}

Rambo $^{29}$ states that theologians have always reflected on questions of human suffering. They have always struggled with the question of how to understand suffering in the world, given the theological claim that God is in a relationship with the world. This discourse, as we all know, is described as the theodicy question. It engages with the presence of suffering, and even evil in the world, and how this is to be reconciled with the claims about the goodness of God. Although theodicies are reactions to unjust suffering and often try to provide theological explanations to the questions which unjust suffering elicits, the degree to which these explanations may or may not help in the healing process is still unsure. ${ }^{30}$

The rise of trauma studies poses new challenges for the theological engagement with suffering. New questions should be asked and the focus should shift to new aspects of the discussion in order to transform the discourse about suffering. According to Rambo "theologians following the conversations about trauma have started to think that trauma calls for a distinctive theological articulation. Unique dimensions of trauma move theology in new directions". ${ }^{31}$ According to this understanding trauma does not belong merely to the fields of psychology and counselling, but it has become part of the theological discourse and presents profound challenges to theological understandings in its entirety. ${ }^{32}$

The merging of trauma studies with theological research may provide theologians with the opportunity of integrating various academic disciplines (with the respective methodologies) and theology with its own approaches. It has thus opened and developed the possibility for interdisciplinary research. Becker states that through literature studies, "we can analyse in more detail how far trauma phenomenology can be used in our understanding of individuals as well as the collective experience of disaster, catastrophe and trauma." ${ }^{, 33}$ Trauma studies have made us aware that the impact of trauma - whether it is felt directly or indirectly - can be experienced by an individual or by the collective group. The ancient texts, as we have them in the Hebrew Bible, provide us with possibilities of how Israel tried to cope and deal with the experiences of trauma and tension. Through their echoes in the literature of the Hebrew Bible, these traumatic experiences do not just come to us in what is said in a straightforward manner, but also in the unsaid. ${ }^{34}$

A number of theologians and biblical scholars who are challenged by the numerous incidents of violence and suffering within the sacred texts, have turned to trauma theory in order to make sense and give theological expression to the violence and suffering. Trauma theory provides a specific perspective for the exegete in order to interpret sacred texts, as 
well as to reconsider the central theological perspectives they offer. ${ }^{35}$ Although it has become evident from the above discussion that the concept of trauma is commonplace in many different contexts, the "use of trauma theory in the field of biblical studies is still in its infancy". 36

In the late 1990s and early 2000s Old Testament scholars once again focused on the Babylonian exile and especially on the impact it had on the people of Judah. Currently the exile is regarded by many scholars as the major driving force behind the creation and preservation of biblical texts. According to Garber $^{37}$ we have also noticed a rise in the application of psychological biblical criticism, poststructuralist and postmodern biblical interpretation, ideological criticism and postcolonial theory in the last couple of decades. These methods also led scholars to interpret the biblical texts in the light of trauma theory. Regarding these recent methodological developments, and specifically the application of trauma theory to biblical texts, Garber makes the important statement that

the use of trauma theory does not constitute a method of interpretation but a frame of reference that, when coupled with diverse forms of biblical criticism, can yield interesting results in the study of the biblical literature and the communities that produced it. Interpretation through the lens of trauma theory has also ventured beyond the narrower concern of exilic literature into the breadth of the biblical corpus. The impact of trauma is no longer the sole purview of an exilic approach, but is part and parcel of the human condition that lies beneath the production of a wide variety of biblical texts. ${ }^{38}$

A basic principle of life is the tension that exists between suffering on the one hand and hope on the other hand. This tension, however, can suffocate hope and cause despair. For Esterhuizen $^{39}$ there is a relationship between suffering and hope, as it not only creates "the possibility of hope in the presence of suffering and despair, but can also influence the way in which suffering is related to hope". It is therefore an imperative for the exegete, when reading the prophetic literature, to develop a sensitivity for the effects trauma can have on individuals and communities. Biblical prophecy creates meaning and hope in the midst of extreme suffering for trauma-stricken communities. ${ }^{40}$

\section{Micah 4:1-5 and the Experience of Trauma}

Micah is the $6^{\text {th }}$ book of the Minor Prophets. The superscription attributes the book to Micah ("Who is like YHWH"), an $8^{\text {th }}$ century BCE prophet from the Judean town of Moresheth. According to this book his prophecies were directed towards the cities of Samaria and Jerusalem. ${ }^{41}$ The reader is not provided with more information about the prophet, except that he was active during the reign of the Judean kings Jotham, Ahaz and Hezekiah. He was thus a contemporary of the prophet Isaiah. Unlike the book of Isaiah, which contains references to the major political events of this part of the history, the book of Micah does not mention them. In spite of this fact the historical period attributed to Micah reflects a time of political and social turmoil, such as the Syro-Ephraimite War and the fall of Samaria which was expected. ${ }^{42}$

The biggest part of the book of Micah was most probably written during the post-exilic period, which opens the book to new interpretations. Instead of being read against the background of an already well-established state, the book's setting is thus a time of imperial invasion and economic development - for some segments of the society. ${ }^{43}$ It is evident that like all other prophetic books, we have to consider a long process of writing and editing until it reached its final composition. ${ }^{44}$

The book of Micah is a complicated text and lacks an apparent overarching narrative. It contains a certain amount of repetition and many themes and concepts are revisited 
repeatedly within the book. ${ }^{45}$ The book is a mixture of judgment and hope. On the one hand it contains prophecies announcing judgment upon Israel for the corrupt leadership, idolatry and social ills. This judgment will end in the destruction of Samaria and Jerusalem. On the other hand, the book of Micah also proclaims the restoration of the nation and the transformation of Israel and Jerusalem. The messages of hope and doom are not necessarily contradictory; however, restoration and transformation will only take place after judgment. $^{46}$

The oracle of Micah 4:1-5, our present text of discussion, is concerned with the exaltation of Zion in the midst of the nations and is probably one of the best-known prophetic texts in the $\mathrm{HB}^{47}$ Its twin version, although in a slightly different form and a different context, appears in the introductory section of the book of Isaiah (Isa. 2:2-4). ${ }^{48}$ The Micah text consists of two sections: 4:1-3, almost parallel to Isa. 2:2-4, and 4:4-5, the ending of the Micah text. ${ }^{49}$ Although the relation of the origin of these two passages has been discussed extensively by other authors, it is beyond the scope of the present article. ${ }^{50}$

Smith-Christopher ${ }^{51}$ suggests that the phrase "in days to come" (4:1) indicates the near future. He challenges the tendency in exegetical literature to interpret this passage as referring to the distant future, as this interpretation would reduce this phrase to have little or even no ethical imperative in the present. This interpretation can put the emphasis on a 'future' interpretation to such a degree that "it becomes more fantasy than vision, a false hope as opposed to a real hope or even a moral statement that could guide contemporary action!"52 An extreme emphasis on the future tense makes the images of beating swords into ploughshares unrealistic and not learning about war.

Jenson $^{53}$ infers that this text, due to its near future orientation, is connected to the preceding section (Mic. 3:9-12) ${ }^{54}$ In contrast to the negative perspective of that section, the orientation of this section is positive and sets the tone for the chapters to follow (chs 4-5). The oracle commences with the vision of the establishment of Mount Zion (v. 1), which is transformed into a centre of the pilgrimage of the nations. They are coming to Zion to receive the Torah and the word of YHWH (vv. 1b-2), as well as justice which will cause the end of all conflict (v. 3a) and lead peace to rule (v. 3b). This text proceeds by stating that every individual will have prosperity and security (v. 4a) and affirms this incredible promise with a divine word (v. 4b). A response to this vision, which formulates a confession of commitment to YHWH, the God of Israel, is added at the end of this oracle (v. 5). ${ }^{55}$

According to Jenson ${ }^{56}$ the text of Micah 4:1-5 stands in direct opposition to the destruction of Jerusalem which was announced in the preceding section in 3:12 ("Assuredly, because of you Zion shall be plowed as a field, and Jerusalem shall become heaps of ruins, and the Temple Mount a shrine in the woods"). This promise also contrasts with the general mood of chs. 1-3 where the nations - the enemies of Israel - were partaking actively in the fulfilment of God's judgment. These two sections (3:9-12 and 4:1:5) contain more contrasts and the following can be mentioned. Whereas in Jerusalem many corrupted the law (3:11), Zion is now transformed to become a centre from which the Torah and the word of YHWH will go forth (4:2). Furthermore: "The city of blood (3:10) that YHWH had abandoned $(3: 12)$ becomes a city of peace $(4: 3 \mathrm{~b})$ where he reigns $(4: 1)$. The city divided against itself $(3: 9-10)$ becomes the centre of international justice and peace $(4: 2-3)$ ". ${ }^{57}$

Smith-Christopher ${ }^{58}$ latches on to Jenson's interpretation and infers that in this text the prophet redefines Jerusalem as an international centre which is no longer only the administrative centre for Judah. There is a profound contrast between the 'former' Jerusalem, which according to 3:12 will be turned upside down, and this new 'Zion', which 
is being transformed from the centre where the Judean elite make their corrupt war plans in order to become an international agrarian centre for reconciliation between the nations. ${ }^{59}$ The only function of the mountain of God is to promote justice and peace between the nations and to teach them the right conduct. It seems evident that a close connection exists between the concepts inherent in the Peace Prophecy (Mic. 4:1-5) and the prophetic critique of ritual worship (e.g. Isa. 1:10-17; Amos 5:21-25; Jer 7; esp. Mic. 6:6-8). Many of the prophets believed justice was lacking, even abandoned, in the rituals of sacrifice. ${ }^{60}$ According to Nogalski ${ }^{61}$ there is a direct causality between the first and the second parts of this verse (4:3), as YHWH's active intervention will lead the nations to destroy all their implements of war and to end all military training. This passage however does not stop with the cessation of war, but is extended to describe a vision of peaceful tranquillity (4.4-5).

Verse 4 sketches the romantic rural farmer's ideal of 'sitting under' a vine and fig tree. In this verse we have the distinctive continuation of the great Peace Prophecy that distinguishes it from the version in the book of Isaiah (Isa. 2). ${ }^{62}$ Agricultural abundance is the one of the promises for the land given by God, according to Deuteronomy 8:7-8, reading as follows: "For the Lord your God is bringing you into a good land, a land with streams and springs and fountains issuing from plain and hill; a land of wheat and barley, of vines, figs, and pomegranates, a land of olive trees and honey" (JPS). Furthermore, it can also suggest a theme of peace to sit with one's vine and fig tree, as in 1 Kings 4:25 [5:5]: "All the days of Solomon, Judah and Israel from Dan to Beer-sheba dwelt in safety, everyone under his own vine and under his own fig tree" (cf. also 2 Kgs 18:31; Isa. 36:16; Joel 2:22; Zech $3: 10 ; 8: 12){ }^{63}$

This message is continued in verse 5 as it reflects on the peace spoken of in the passage as a whole. It visualises a peaceful coexistence among the nations and their gods and indicates recognition of the current state of the world. On the other hand, this verse represents a significant shift from the message of Micah 4:2-3, which speak of the nations who are coming to Jerusalem to worship YHWH and are settling for a peace agreement between them. Although there is definitely no reference to a mass conversion to the 'ways' of YHWH in these verses, it nonetheless is a hopeful image that the other nations continue to walk in their own ways without threatening Israel. ${ }^{64}$

\section{Conclusion}

Smith-Christopher ${ }^{65}$ appropriately states that "Micah 4:1-5 is quite possibly the most dramatic anti-war sentiment expressed in the entire Hebrew Bible". The portrayal of trauma underlying this text becomes clear when we consider its Sitz im Buch. This text follows the announcement of the destruction of Jerusalem together with the temple in $3: 12$. The introduction of such an action within the world of the text arouses pictures of chaos and trauma from the reader's perspective of the text. ${ }^{66}$ This invites the reader to imagine the sound, smell and sight of the destruction and of the burning of the devastated surface of a cultivated city. ${ }^{67}$ From the reader's perspective this breakdown and subsequent chaos threatens the way in which "the Jerusalem-centred world is structured both in the world of the text and in the worldview of the reader". ${ }^{68}$ In Micah the destruction of Jerusalem is explained in terms of the incredible sins of the elite of the society.

In this regard Smith-Christopher ${ }^{69}$ emphasises Micha's criticism of Jerusalem's military policies. This critique can be described as an agrarian anti-war criticism directed against the trauma caused by the military policies of Jerusalem's elite. These policies were a disaster for the people living in the Shephelah as well as in Micah's Moresheth. Micah 4:1-5 fits well into the radical social message of the book as a whole. What is clear is that the wish to 
turn weapons into farming tools reflects the voices of protest coming from the Judean agricultural sector. By thus transforming the reading of Micah 4:1-5 to an agrarian anti-war protest, the angry voice of Micah from Moresheth is restored. ${ }^{70}$ This angry voice is a voice of protest against the trauma caused by the politics of the governing elite in Jerusalem.

\section{BIBLIOGRAPHY}

Becker, Eve-Marie. “"Trauma Studies' and Exegesis: Challenges, Limits and Prospects.”

Pages 15-29 in Trauma and Traumatization in Individual and Collective Dimensions:

Insights from Biblical Studies and Beyond. SANt 2; Edited by Eve-Marie Becker,

Jan Dochhorn \& Else K. Holt. Göttingen: Vandenhoeck \& Ruprecht, 2014.

Ben Zvi, Ehud. Micah. FOTL 21B. Grand Rapids, MI: William B. Eerdmans, 2000.

Claassens, L. Juliana M. \& Garber, David G. "First Words ... Faith Facing Trauma".

Review and Expositor 105 (2008):187-190.

Collins, John J. Introduction to the Hebrew Bible. Minneapolis, MN: Fortress Press, 2004.

Coomber, Matthew J.M. "Micah." Pages 871-884 in The Old Testament and Apocrypha.

Fortress Commentary on the Bible. Edited by Gale A. Yee, Hugh R. Page \& Matthew J.

M. Coomber. Minneapolis, MN: Fortress Press, 2014.

Esterhuizen, Elizabeth. A Study of the Tension between Despair and Hope in Isaiah 7 and 8 from a Perspective of Trauma and Posttraumatic Growth. Pretoria (Unpublished DThThesis University of South Africa (Unisa), 2017.

Frechette, Christopher G. \& Boase, Elizabeth. "Defining 'Trauma' as a Useful Lens for Biblical Interpretation." Pages 1-23 in Bible through the Lens of Trauma. Edited by Christopher G. Frechette \& Elizabeth Boase. Atlanta, GA: SBL Press, 2016.

Garber, David G. "Trauma Theory." Pages 421-428 in The Oxford Encyclopedia of Biblical Interpretation vol, 2. Edited by Steven L. Mckenzie. Oxford/New York: Oxford University Press, 2013.

Garber, David G. "Trauma Theory and Biblical Studies.” CBR 14/1 (2015):24-44.

Groenewald, Alphonso. "Isaiah 2:1-5: A Post-Exilic Vision of the Pilgrimage of the Nations to Zion." Pages 53-69 in Zugänge zum Fremden. Methodisch-hermeneutische Perspektiven zu einem biblischen Thema. Edited by Gerlinde Bauman, Susanne Gillmayr-Bucher, Maria Häusl \& Dirk J. Human. Linzer Philosophisch-Theologische Beiträge 25; Frankfurt a.M.: Peter Lang, 2012.

Groenewald, Alphonso. "The Significance of תורה (Isa. 2:3) within Isaiah 2:1-5: The Relationship of the First Overture (1:1-2:5) to the Book's Conclusion (Isa. 65-66)." OTE 26/3 (2013):695-717.

Herman, Judith L. Trauma and Recovery. The Aftermath of Violence - From Domestic Abuse to Political Terror. New York, NY: Basic Books, 2015.

Janoff-Bulman, Ronnie. Shattered Assumptions. Towards a new Psychology of Trauma. New York, NY: Free Press, 1992.

Janzen, David. The Violent Gift. Trauma's Subversion of the Deuteronomistic History's Narrative. LHB/OTS 561. New York/London: Bloomsbury, 2012.

Jenson, Philip P. Obadiah, Jonah, Micah. A Theological Commentary. New York/London: T\&T Clark, 2008.

Mills, Mary E. Alterity, Pain, and Suffering in Isaiah, Jeremiah, and Ezekiel. LHB/OTS 479. London/New York: T\&T Clark, 2007. 
Nogalski, James D. The Book of the Twelve: Micah - Malachi. Macon, GA: Smyth \& Helwys, 2011.

O'Connor, Kathleen M. Jeremiah: Pain and Promise. Minneapolis, MN: Fortress Press, 2011.

Rambo, Shelly. Spirit and Trauma. A Theology of Remaining. Louisville, KY:

Westminster/John Knox Press, 2010.

Shaw, Charles S. "Micah, Book of.” Pages 893-895 in Eerdmans Dictionary of the Bible. Edited by David N. Freedman. Grand Rapids/Cambridge: William B. Eerdmans, 2000.

Smith-Christopher, Daniel L. Micah: A Commentary. OTL. Louisville, KY:

Westminster/John Knox, 2015.

Stulman, Louis \& Kim, H.C. Paul. You are my People: An Introduction to Prophetic Literature. Nashville, TN: Abingdon Press, 2010.

Sweeney, Marvin A. The Twelve Prophets. Volume Two: Micah, Nahum, Habakkuk, Zephaniah, Haggai, Zechariah, Malachi. Berit Olam. Collegeville, MN: Liturgical Press, 2000.

Van der Kolk, Bessel A. The Body Keeps the Score. Brain, Mind, and Body in the Healing of Trauma. New York, NY: Penguin Books, 2014.

Waltke, Bruce K. A Commentary on Micah. Grand Rapids, MI: William B. Eerdmans, 2007.

Westermann, Claus. "The Role of Lament in the Theology of the Old Testament". Interpretation 28/1 (1974): 20-38.

\section{Endnotes}

1 This article is dedicated to the role Prof. Hendrik Bosman played in stimulating and fostering the study of the Prophets and Prophetic Literature in South Africa and on the African continent as a whole.

2 Bessel A. van der Kolk, The Body Keeps the Score. Brain, Mind, and Body in the Healing of Trauma (New York, NY: Penguin Books, 2014), 1-2.

3 L. Juliana. M. Claassens and David G. Garber, "First Words ... Faith Facing Trauma", Review and Expositor 105 (2008):187-190, here p. 187-188. Cf. also Mary E. Mills, Alterity, Pain, and Suffering in Isaiah, Jeremiah, and Ezekiel (LHB/OTS 479; London/New York: T\&T Clark, 2007).

4 Claassens \& Garber, "First Words", 187-188.

5 Ronnie Janoff-Bulman, Shattered Assumptions. Towards a new Psychology of Trauma. (New York, NY: Free Press, 1992), 59-60.

6 Janoff-Bulman, Shattered Assumptions, 60.

7 Elizabeth Esterhuizen, A Study of the Tension between Despair and Hope in Isaiah 7 and 8 from a Perspective of Trauma and Postraumatic Growth (Pretoria; Unpublished DTh-Thesis Unisa, 2017), 20.

8 David G. Garber, "Trauma Theory," in The Oxford Encyclopedia of Biblical Interpretation, vol. 2 (ed. S.L. McKenzie (Oxford/New York: Oxford University Press, 2013), 421-428, here p. 427.

9 Christopher G. Frechette \& Elizabeth Boase, "Defining 'Trauma' as a Useful Lens for Biblical Interpretation," in Bible through the Lens of Trauma, eds. C.G. Frechette \& E. Boase (Atlanta, GA: SBL Press, 2016), 1-23, here 12.

10 Claus Westermann, “The Role of Lament in the Theology of the Old Testament". Interpretation 28/1 (1974):20-38, here p. 31.

11 Frechette \& Boase, "Defining 'Trauma'," 12-13.

12 Esterhuizen, "A Study of the Tension," 20. 

Terror (New York, NY: Basic Books, 2015).

\section{Trauma, $3 \mathrm{f}$}

Eve-Marie Becker, "'Trauma Studies' and Exegesis: Challenges, Limits and Prospects," in Trauma and

Traumatization in Individual and Collective Dimensions: Insights from Biblical Studies and Beyond, eds.

Eve-Marie Becker, Jan Dochhorn \& Else K. Holt (SANt 2; Göttingen: Vandenhoeck \& Ruprecht, 2014), 15-29, here p. 25.

\section{(1)} Matthew J.M. Coomber (Fortress Commentary on the Bible; Minneapolis, MN: Fortress Press, 2014), 871-884, here p. 871. Rapids/Cambridge: William B. Eerdmans, 2000), 893-895, here pp. 893-894. Esterhuizen, A Study of the Tension, 21.

Rambo, Spirit and Trauma, 3 and Esterhuizen, A Study of the Tension, 21.

Herman, Trauma and Recovery, 7-9.

Esterhuizen, A Study of the Tension, 21-22.

Rambo, Spirit and Trauma, 4.

Esterhuizen, A Study of the Tension, 23-24. Cf. also Rambo, Spirit and Trauma, 3f.

Kathleen M. O’Connor, Jeremiah: Pain and Promise (Minneapolis, MN: Fortress Press, 2011), 2.

Rambo, Spirit and Trauma, 3.

Cf. also David Janzen, The Violent Gift. Trauma's Subversion of the Deuteronomistic History's Narrative DTS 561; New York/London: Bloomsbury, 2012), 28 stating as follows in this regard: "In Beyond the Pleasure Principle, published two years after the war, Freud refers to the 'traumatic neurosis' observed in those exposed to combat, and notes that it involves intrusion into the dream lives of the victims. Just as in the case of those who suffer from hysteria, Freud points out, the repetitive return of the trauma in dreams causes the patient to become 'fixated' to the trauma, thereby upsetting the normal healing nature of dreams".

Rambo, Spirit and Trauma, 19

Rambo, Spirit and Trauma, 4.

Rambo, Spirit and Trauma, 4.

Rambo, Spirit and Trauma, 4.

Rambo, Spirit and Trauma, 4-5.

Rambo, Spirit and Trauma, 5.

Esterhuizen, A Study of the Tension, 4, 8.

Rambo, Spirit and Trauma, 30.

Janzen, The Violent Gift, 238.

David G. Garber, "Trauma Theory and Biblical Studies," CBR 14/1 (2015): 24-44, here p. 24-25.

Garber, "Trauma Theory and Biblical Studies," 25.

Esterhuizen, A Study of the Tension, 43.

Esterhuizen, A Study of the Tension, 43-44. Cf. also Louis Stulman \& H. C. Paul Kim, You are my People: An Introduction to Prophetic Literature (Nashville, TN: Abingdon Press, 2010), p. 7.

Coomber, Micah, 872.

John J. Collins, Introduction to the Hebrew Bible (Minneapolis, MN: Fortress Press, 2004), 321.

Coomber, Micah, 872.

Shaw, Micah, 894.

Shelly Rambo, Spirit and Trauma. A Theology of Remaining (Louisville, KY: Westminster/John Knox Press, 

Zechariah, Malachi (Berit Olam; Collegeville, MN: Liturgical Press, 2000), 377. Nations to Zion", in Zugänge zum Fremden. Methodisch-hermeneutische Perspektiven zu einem biblischen Thema, eds. G. Baumann, S. Gillmayr-Bucher, M. Häusl and D.J. Human, Linzer Philosophisch-Theologische תורה (Isa. 2:3) within Isaiah 2:1-5: The Relationship of the First Overture (1:1-2:5) to the Book's Conclusion (Isa. 65-66)," OTE 26/3 (2013):695-717.

Sweeney, The Twelve Prophets, 377. Cf. also
MI: William B. Eerdmans, 2007), 191-192.

51 Smith-Christopher, Daniel L. Micah: A Commentary (OTL; Louisville, KY: Westminster/John Knox, 2015), 130.

Smith-Christopher, Micah, 130.

Philip P. Jenson, Obadiah, Jonah, Micah. A Theological Commentary (New York/London: T\&T Clark, 2008), 142.

54 Smith-Christopher, Micah, p. 132 supports this perspective when he infers as follows: "I am aware that I am challenging the weight of opinion by suggesting that this assumed 'break' between the notions of 3:12 and 4:1-5 is false".

55 Jenson, Micah, 142.

56 Jenson, Micah, 142.

57 Jenson, Micah, 143.

58 Smith-Christopher, Micah, 132.

Smith-Christopher, Micah, 132

Nogalski, The Book of the Twelve, 557.

Smith-Christopher, Micah, 136.

Smith-Christopher, Micah, 136-137.

Nogalski, The Book of the Twelve, 557 and Smith-Christopher, Micah, 138.

Smith-Christopher, Micah, 139.

Ehud Ben Zvi, Micah (FOTL 21B; Grand Rapids, MI: William B. Eerdmans, 2000), 104.

Cf. also Mills, Alterity, Pain, and Suffering, 39.

Ben Zvi, Micah, 104.

Smith-Christopher, Micah, 144-145.

Smith-Christopher, Micah, 144-145. 